\title{
Defective trophoblast function in mice with a targeted mutation of Ets2
}

\author{
Hideyuki Yamamoto, ${ }^{1}$ Margaret L. Flannery, ${ }^{2}$ Sergey Kupriyanov, ${ }^{1}$ Jonathan Pearce, ${ }^{3}$ \\ Scott R. McKercher, ${ }^{1}$ Gregory W. Henke, ${ }^{1}$ Richard A. Maki, ${ }^{1}$ Zena Werb, ${ }^{2}$ \\ and Robert G. Oshima ${ }^{1,4}$ \\ ${ }^{1}$ The Burnham Institute, La Jolla, California 92037 USA; ${ }^{2}$ Department of Anatomy, University of California, San Francisco, \\ San Francisco, California 94143 USA; ${ }^{3}$ Samuel Lunenfeld Research Institute, M ount Sinai Hospital, Toronto, Canada
}

\begin{abstract}
Members of the Ets family of transcription factors mediate transcriptional responses of multiple signaling pathways in diverse cell types and organisms. Targeted deletion of the conserved DNA binding domain of the Ets2 transcription factor results in the retardation and death of homozygous mouse embryos before 8.5 days of embryonic development. Defects in extraembryonic tissue gene expression and function include deficient expression of matrix metal loproteinase-9 (MMP-9, gelatinase B), persistent extracel lular matrix, and failure of ectoplacental cone proliferation. Mutant embryos were rescued by aggregation with tetraploid mouse embryos, which complement the developmental defects by providing functional extraembryonic tissues. Rescued Ets2-deficient mice are viable and fertile but have wavy hair, curly whiskers, and abnormal hair follicle shape and arrangement, resembling mice with mutations of the EGF receptor or its ligands. However, these mice are not deficient in the production of TGF $\alpha$ or the EGF receptor. Homozygous mutant cell lines respond mitogenically to TGF $\alpha$, EGF, FGF1, and FGF2. However, FGF fails to induce MMP-13 (collagenase-3) and MMP-3 (stromelysin-1) in the Ets2-deficient fibroblasts. Ectopic expression of Ets2 in the deficient fibroblasts restores expression of both matrix metal loproteinases. Therefore, Ets2 is essential for placental function, mediating growth factor signaling to key target genes including MMP-3, MMP-9, and MMP-13 in different cell types, and for regulating hair development.
\end{abstract}

[Key Words: Ets2; trophoblast; proteinase; FGF; TGF $\alpha$; transcription]

Received January 23, 1998; revised version accepted March 2, 1998.

The Ets family of transcription factors is composed of over 30 members, characterized by the presence of a variant winged helix-turn-helix motif used for DN A binding (Karim et al. 1990; Donaldson et al. 1994; Liang et al. 1994; Kodandapani et al. 1996; Ghysdael and Boureux 1997). A subset of Ets proteins contain a region of 65-100 residues called the pointed or $B$ domain, which has been implicated in signal transduction. In Drosophila, two Ets factors, the PNT-P2 product of the pointed gene and YAN / Pokkuri, mediate signaling by the sevenless/Ras/ RAF/MAP kinase pathway, essential for the R7 photoreceptor cell development (Brunner et al. 1994; O'N eill et al . 1994). Similarly, in Caenorhabditis el egans, the Ets transcription factor LIN-1 acts downstream of an EGF/ EGF-R/MAP kinase signaling pathway to negatively regulate vulval cell fate (Beitel et al. 1995). The vertebrate Ets1 and Ets2 are most similar to PNT-P2 in both the Ets and pointed domains. Activation of signaling by a mutant neu (Erb-B2), a member of the EGF receptor family, or by v-src, ras, or raf, stimulates the transcriptional activity of both Ets1 and Ets2. This stimulation is

${ }^{4}$ Corresponding author.

E-MAIL rgoshima@jcrf.edu; FAX (619) 646-3193. dependent upon the phosphorylation of specific threonine residues within the pointed domains (Rabault et al. 1996; Yang et al. 1996). Ets1 and Ets2 cooperate with other transcription factors including AP-1, M afB, SP-1, Pax5, Pit1, N FkB, E2F-1, and GATA-1 to stimulate transcription of a wide variety of genes (Ghysdael and Boureux 1997). Ets1 is less widel y expressed than Ets2 in adult tissues and is important for T-cell survival and function (Muthusamy et al. 1995). Ets2 is expressed in many cell types in developing mouse embryos, including limb buds and the embryonic skin, in a pattern overlapping but also largely distinct from Etsl (Maroulakou et al. 1994).

The number of genes known to utilize Ets binding sites is large and include those coding for transcription factors (Ets1, JunB, TBP, NFkB, c-Fos, GATA-1, Myc), matrix-degrading proteinases (stromelysin-1, collagenase-1, urokinase-type plasminogen activator, gel atinase B), keratins Endo A (mouse K8) and Endo B (mouse K18), cell cycle regulators (p53, cyclin D1), extracellular matrix receptors and ligands (integrins $\alpha \mathrm{V}, \alpha 2, \beta 2$, and osteopontin), and growth factors (HB-EGF). However, the similar DN A-binding specificity of multiple members of the Ets family, and the extensive cooperation with other 
transcription factors has made it difficult to identify specific target genes with certai nty. To eval uate the bi ological importance of Ets2 on gene expression and mammalian development, we have mutated the gene by gene targeting, and have generated cells and mice with no wild-type Ets2 product. Ets2 is a critical regulator of extraembryonic tissue function and hair development.

\section{Results}

\section{Targeted mutagenesis of ets2}

The mouse ets2 gene was targeted by homologous recombination in D3 ES cells with a vector that replaced all or part of three exons of the gene coding for the Ets DNA binding domain with the pMC1N eoA selectable gene (Henkel et al. 1996). The mutant ets2 gene was expected to either be null or code for a protein that lacks DNA binding activity and the signals necessary for nuclear localization (Boulukos et al. 1989). Six targeted ES cell clones were identified from a total of 109 screened colonies by Southern blot analysis, with probes flanking the sequence included in the targeting vector, and a third probe within the neo gene. (Supplemental data not shown are available at http:// www.burnhaminst.org/papers/ets2.) The results confirmed the expected arrangement of the targeted gene, which was designated ets $2^{\mathrm{db} 1}$ for DN A-binding domain mutant 1 . An ES cell line carrying two targeted alleles was generated by cultivation of a targeted ES cell clone in increasing concentrations of G418 (Henkel et al. 1996). The homozygous clone was used for the generation of teratocarcinoma tumors and the isolation of cell lines.

ets $2^{\mathrm{db} 1}$ lacks the DNA-binding domain and is located in the cytoplasm

RNase protection analysis confirmed the absence of wild-type RN A in ES cells and fibroblastic cells containing two targeted alleles (Fig. 1A). However, ets2 ${ }^{\mathrm{db} 1 / \mathrm{db} 1}$ cells expressed normal levels of a slightly larger RN A, which hybridized with a probe for the $5^{\prime}$ end of the ets 2
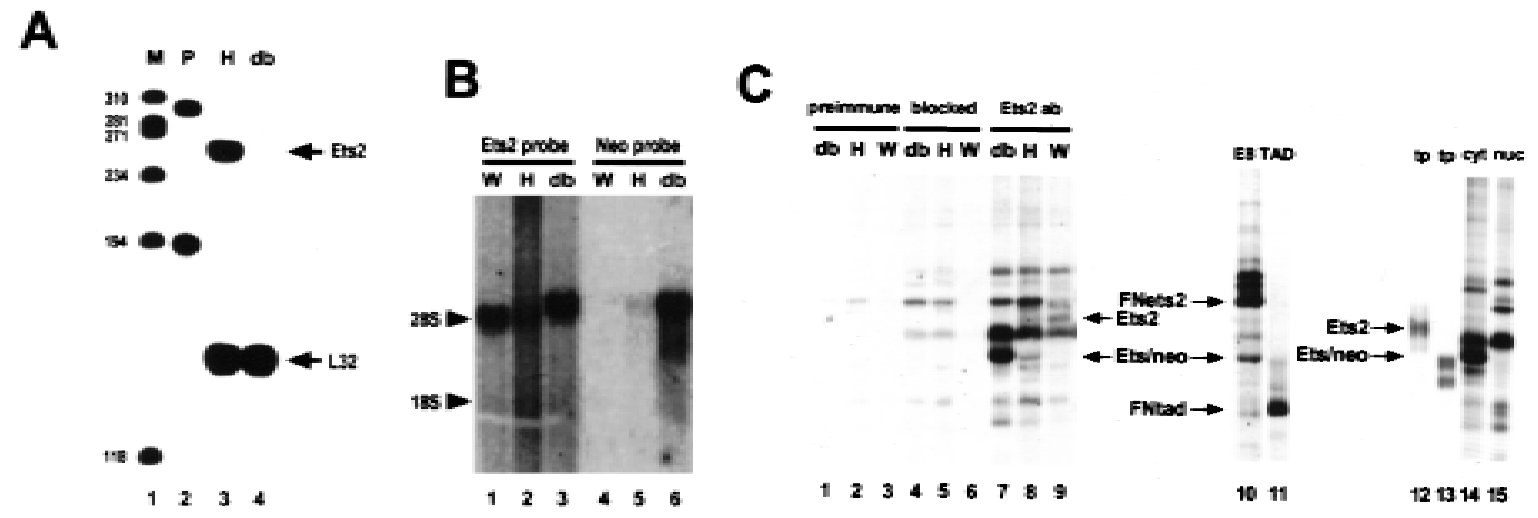

Figure 1. RNA and protein expression from the ets $2^{\mathrm{db} 1}$ targeted allele. (A) RN ase protection analysis of RN A derived from ets $2^{\mathrm{db} 1 /+}$ and ets2 ${ }^{\mathrm{db} 1 / \mathrm{db} 1}$ fibroblast lines utilizing a DNA binding domain probe. (Lane 1) size markers ( $M$ ); (lane 2) probes (P) for Ets2 (upper) and the L32 ribosomal protein RNA (lower); (lane 3) ets $2^{\mathrm{db} 1 /+}(\mathrm{H})$ RN A; (lane 4) ets2 ${ }^{\mathrm{db} 1 / \mathrm{db} 1}$ homozygous (db) RN A. (B) N orthern bl ot analysis of $5 \mu \mathrm{g}$ of poly $(\mathrm{A})^{+} \mathrm{RN} A$ from the same cell lines. A probe from the $5^{\prime}$ end of the ets2 CDNA detected ets2-related RNA in wild-type $(W)$, heterozygous $(H)$, and homozygous (db) cells. A neo probe detects RNA only in heterozygous ets $2^{\mathrm{db} 1 /+}$ (lane 5) and ets2 ${ }^{\mathrm{db} 1 / \mathrm{db} 1}$ RN A (lane 6). (C) Immunoprecipitation analysis of Ets2 and Ets $2^{\mathrm{db} 1}$ proteins. Ets2 antiserum (M cC arthy et al. 1997) detects the wild-type Ets2 protein (Iane 9, Ets2), the product of the ets2 ${ }^{\mathrm{db} 1}$ allele (lanes 7,10,14, Ets/neo), an epitope-tagged form of Ets2 (lane 10, FN ets2) and an epitope-tagged form of the transactivation do-

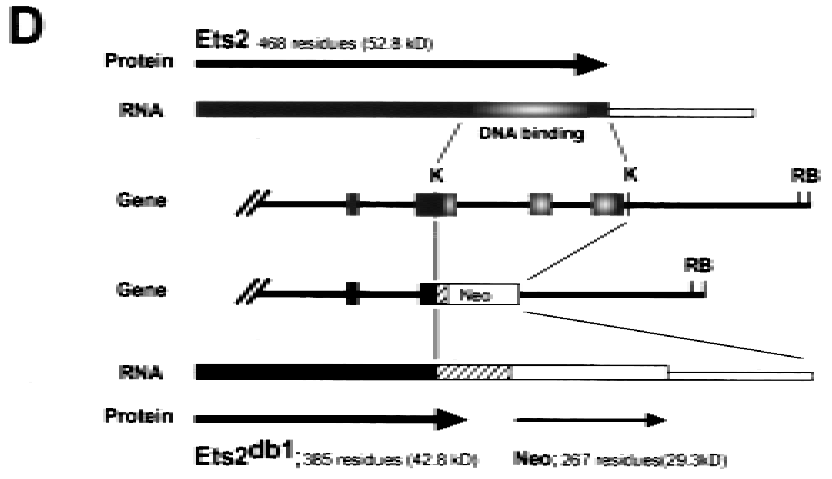
main of Ets2 (lane 11, FN tad). N o specific signal was detected with preimmune serum (lanes 1-3) or Ets2 antiserum incubated with excess recombinant Ets2 (lanes 4-6). Translation products of ets2 mRNA (lane 12) and the ets2/neo fusion transcript (lane 13). The supernant fraction (cyt) and solubilized pellet (nuc) fractions of ets $2^{\mathrm{db} 1 / \mathrm{db} 1}$ cells were immunoprecipitated with Ets2 antiserum (lanes 14,15). The ets2 $2^{\mathrm{db} 1 / \mathrm{db} 1}$, ets2 ${ }^{\mathrm{db} 1 /+}$, and ets $2^{+1+}$ cell types are EKO1, EHT 1, and $3 T 3$ cells, respectively. E8 is a rescued cl one of EKO1 that expressed the FN ets2 protein (lane 10). (Lane 11) Control cells expressing FN tad. (D) Schematic representation of ets2 and ets2 ${ }^{\mathrm{db} 1}$ genes, RN As, and proteins. The structures of the $3^{\prime}$ end of the wild-type and targeted genes are shown in the middle with solid boxes representing exons. The regions coding for the DN A-binding domain are shaded. The position of the pM C IneoA gene is label ed $\mathrm{N}$ eo with promoter/enhancer region represented as crosshatched. The predicted RN As for the two genes are shown at the top and bottom. The expected 3' noncoding region of both mRN As are represented by the smaller open rectangles at the right. The proteins coded for by the RNAs are indicted by the arrows with the expected size indicated. 
mRN A (Fig. 1B, lane 3). This fusion transcript appears to arise from transcription through the $\mathrm{PMC}$ C neo promoter into the large 3'-untranslated portion of ets2 RN A (Watson et al. 1990) because it contained neo coding sequences (Fig. 1B, lanes 5,6). The fusion mRNA from the targeted ets 2 allele is predicted to have an open reading frame that extends 77 codons downstream of the fusion site within exon 8 (codon 308) (Fig. 1D). This product could be active as an inhibitor. However, both the preferential cytoplasmic localization and the del etion of the Ets domain would hinder the transcriptional activation potential of the ets 2 gene product. The targeting of the ets 2 gene results in a deletion of a critical portion of the gene but does not result in a null allele.

Ets2 protein was expressed at very low levels in wildtype cells, as expected from the reported rapid turnover of the protein (Fig. 1C, lane 9) (Fujiwara et al. 1988). However, its identity was confirmed by its absence from ets2 ${ }^{\mathrm{db} 1 / \mathrm{db} 1}$ cells (lanes 7,10), its comigration with in vitro synthesized Ets2 (lane 12; data not shown) and its sensitivity to preabsorption with recombinant Ets2. In both ets $2^{\mathrm{db} 1 / \mathrm{db} 1}$ and ets $2^{\mathrm{db} 1 /+}$ cells, we identified a faster migrating protein that was specifically precipitated by the Ets2 antiserum (McCarthy et al. 1997) but not by blocked antibody (Fig. 1C, lanes 7,8, ets/neo). This protein comigrated with a cell-free translation product of a synthetic RN A representing the expected fusion of the $3^{\prime}$ truncated ets 2 cDNA and the pMClneo gene (lanes $12,13)$. Fractionation of the ets $2^{\mathrm{db} 1 / \mathrm{db} 1}$ cells into nuclear and cytoplasmic fractions confirmed that the ets $2^{\mathrm{db} 1}$ protein was found only in the cytoplasmic compartment (Fig. 1C, lanes 14,15).

\section{Ets2 is required for embryonic development}

Chimeric animals were generated by the injection of the ets $2^{\mathrm{db} 1 /+}$ ES cells into C57/BI6 blastocysts. Transmission of the targeted allele to subsequent progeny of both Swiss BI and 129/Sv strain of mice was confirmed by both Southern bl ot analysis and PCR. Heterozygous animals in both genetic background appear heal thy, fertile, and normal. However, no ets $2^{\mathrm{db} 1 / \mathrm{db} 1}$ homozygous animals were detected from 449 progeny of ets $2^{\mathrm{db} 1 /+}$ heterozygote parents (Table 1). Thus, homozygosity for the ets $2^{\mathrm{db} 1}$ allele results in embryonic lethality. Heterozygote adults represented $59 \%$ of the total. When heterozygote crosses were analyzed after varying times of development to determine the time of embryonic death, no ets2 ${ }^{\mathrm{db} 1 / \mathrm{db} 1}$ embryos were recovered at either E11.5 or E8.5 (Table 1). Instead, residual, empty, and smaller de-

Table 1. Embryonic lethality of ets $2^{\mathrm{db} 1}$ mice

\begin{tabular}{lrrrcc}
\hline & $\begin{array}{c}\text { Total } \\
\text { no. }\end{array}$ & ets2 $^{+++}$ & ets2 $^{\text {db1/+ }}$ & ets2 $^{\text {db1/db1 }}$ & $\begin{array}{c}\text { Empty } \\
\text { decidua }\end{array}$ \\
\hline Adult & 449 & 184 & 265 & 0 & - \\
11.5 day & 27 & 10 & 17 & 0 & $7(26 \%)$ \\
8.5 day & 41 & 19 & 22 & 0 & $8(20 \%)$ \\
7.5 day & 57 & 15 & 28 & 14 & $0(0 \%)$ \\
Blastocyst & 133 & 22 & 82 & 29 & - \\
\hline
\end{tabular}

A

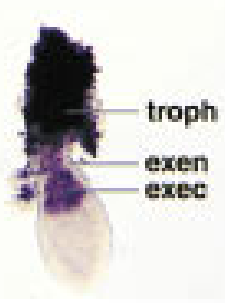

B

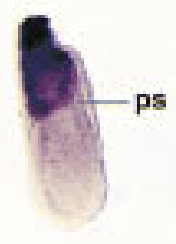

C

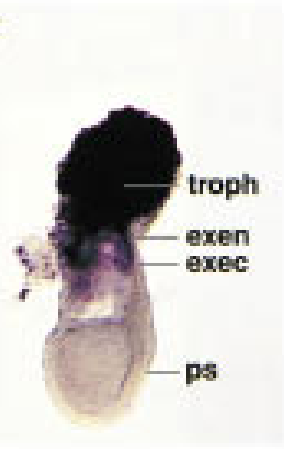

D
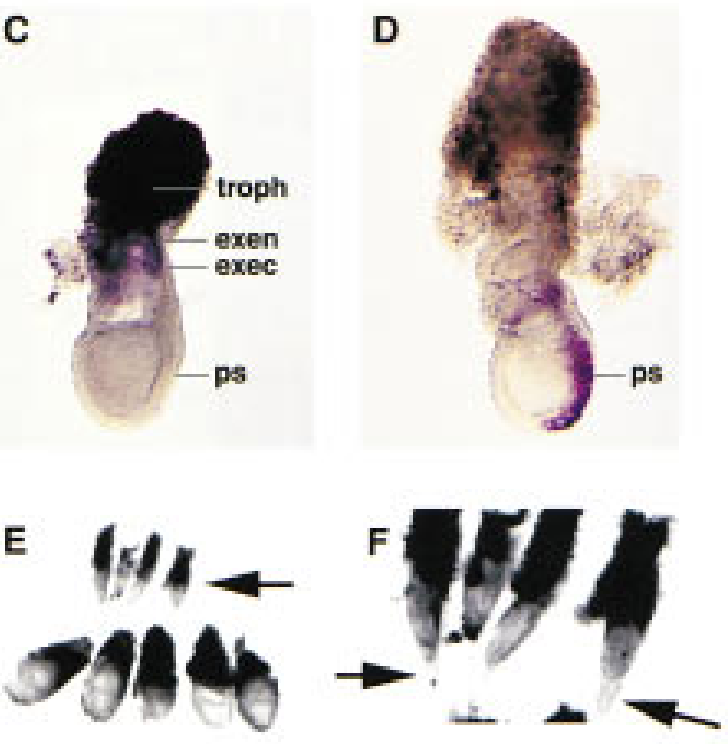

Figure 2. In situ localization of ets2 RN A and retarded growth of ets2 ${ }^{\mathrm{db} 1 / \mathrm{db} 1}$ embryos. Whole mount in situ analysis of ets2 expression in E6-E7.5 embryos. (A) At E6, prior to primitive streak (ps) formation, expression is seen in the extraembryonic ectoderm (exec) and trophectoderm (troph), but not in the overlying extraembryonic endoderm (exen). (B) Primitive streak stage at E6.5 and el ongated at E7.5 (C). (D) Brachyury (T) expression at E7.5, used as a control. (E) Embryos resulting from a mating of ets $2^{\mathrm{db} 1 /+}$ parents were dissected at E7.5 days. The four small embryos were subsequently identified as ets $2^{\mathrm{db} 1 / \mathrm{db} 1}$. The trophoblastic tissue was removed from the normal sized embryos. (F) A higher magnification showing the unusual coneshaped yolk sac of the arrested ets $2^{\mathrm{db} 1 / \mathrm{db} 1}$ embryos.

cidual swellings were seen. The same result was found in the $129 /$ Sv background and after five generations in the Swiss/BI background.

\section{Expression of ets2 in early embryos}

In situ hybridization of ets2 RNA revealed very high levels of the RNA in the trophoblastic tissues of E6.0-E7.5 embryos and lower levels of expression in the extraembryonic ectoderm and trophectoderm, but not in the overlying extraembryonic endoderm or primary embryonic ectoderm (Fig. 2A-C). Brachyury (T) expression at E7.5 was used as a control to show that the ets2 expression seen in the trophectoderm and extraembryonic ectoderm was not due to probe trapping (Fig. 2D).

ets $2^{\mathrm{db} 1 / \mathrm{db} 1}$ conceptuses have extraembryonic defects

Blastocysts recovered from heterozygote matings at E3.5 
days appeared normal. In culture, the blastocysts attached to either plastic- or extracellular-matrix-coated surfaces and generated trophoblast outgrowths that were not distinguishabl e between genotypes (data not shown). At E7.5, 14 of 57 decidual swellings contained much smaller embryos (Fig. 2E) with an unusual cone-shaped yolk sac/trophoblast envelope (Fig. 2F) and a much smaller amount of attached trophoblastic tissue. PCR analysis of the embryonic portion of these embryos confirmed they were all ets2 ${ }^{\mathrm{db} 1 / \mathrm{db} 1}$. Histological analysis of embryos at E6.5 and E7.5 days revealed multiple defects in ets2 ${ }^{\mathrm{db} 1 / \mathrm{db} 1}$ embryos (Fig. 3). At E6.5, mutant embryos were distinguished by a small ectoplacental cone region, apparently caused by a failure of trophoblast migration (Fig. 3B). A membrane appeared to cover the ectoplacental cone, which may prevent trophoblast migration. At E7.5 days ets $2^{\mathrm{db} 1 / \mathrm{db} 1}$ embryos were much smaller than normal embryos (Fig. 3E; note scale). Neither amnion nor chorion membranes formed, resulting in embryos with only one, rather than three cavities. The trophoblastic tissue in the EPC failed to proliferate, and the primary ectoderm began to die by apoptosis, as indicated by pynotic nuclei (Fig. 3F). Many cells in the primary ectoderm were positive by TUNEL staining of DNA breaks (data not shown). The absence of the chorion and amnion membrane divisions suggests that the embryo failed before or early in gastrulation, which generates both extraembryonic and embryonic mesoderm. By E8.5, no ets $2^{\mathrm{db} 1 / \mathrm{db} 1}$ embryos were identified; instead, bloody and largely empty implantation sites showed that the mutant embryos had been resorbed.

The growth retardation of E7.5 ets2 ${ }^{\mathrm{db} 1 / \mathrm{db} 1}$ embryos might be attributed to defects in trophoblastic cells in establishing appropriate interaction with the maternal circulation. M M P-9 (gel atinase B), a matrix metalloproteinase and marker of trophoblastic cells at this stage, was dramatically reduced in mutant embryos (Fig. 4A,B). The ets $2^{\mathrm{db} 1 / \mathrm{db} 1}$ embryos showed much decreased immunohistochemical staining of PECAM-1, an endothelial marker also expressed in trophoblast cells directly con- nected to maternal endothelium (Vecchi et al . 1994) (Fig. 4G,H). However, not all trophoblastic gene expression was inhibited. Expression of placental lactogen-1, a hormone secreted by trophoblast cells, was upregulated in mutant embryos (Fig. 4C,D). Laminin, a basement membrane component of Reichert's membrane, was found in ets2 ${ }^{\mathrm{db} 1 / \mathrm{db} 1}$ embryos (Fig. 4E,F) and extended into and over the trophoblast. The unusual continuity of the pre sumptive Reichert's membrane may reflect the low expression of metall oproteinases such as M M P-9 and likely contributes to the unusual trophoblast/yolk sac enve lopes noted in dissected embryos (Fig. 2E,F). These re sults indicate that the ets $2^{\mathrm{db} 1 / \mathrm{db} 1}$ embryos had abnormalities of trophobl ast gene expression, poor connection with the maternal circulation, and possible abnormalities in basement membrane metabolism that, together, could contribute to embryonic death.

\section{ets2 $2^{\mathrm{db} 1 / \mathrm{db} 1}$ ES cells can contribute to aggregation} chimeras with normal embryos

Thehistol ogical examination of ets $2^{\mathrm{db} 1 / \mathrm{db} 1}$ embryos and the in vitro differentiation of ets2 ${ }^{\mathrm{db} 1 / \mathrm{db} 1}$ ES cells (data not shown) implicated defects in extraembryonic tissue. To eval uate whether the embryonic tissues were also affected, we performed two types of cellular rescue experiments. First, ets2 ${ }^{\mathrm{db} 1 / \mathrm{db} 1}$ ES cells were injected into C57/BI6 mouse blastocysts, which were then transferred to foster mothers and sacrificed at E18.5. M orphologically normal chimeric embryos formed. The ES cells contributed to the brain, lung, heart, liver, spleen, gut, and kidney, as assessed by the presence of the B isoform of glucose-6-phosphate isomerase from the strain $129 \mathrm{ES}$, in addition to the C57/BI6 A isoform. The contribution of the $B$ isoform provided by the ets $2^{\mathrm{db} 1 / \mathrm{db} 1} \mathrm{ES}$ cells ranged from $5 \%$ to $20 \%$ of the total GPI enzyme activity (data not shown). Contribution to heart was higher with values from $15 \%$ to $45 \%$ of the total activity. Thus the ets2 ${ }^{\mathrm{db} 1 / \mathrm{db} 1}$ ES cells were capable of contributing to normal development of major organ systems.
Figure 3. Abnormal implantation in Ets2 mutant embryos. (A,D), normal implantation in E6.5 and E7.5 wild-type embryos in which the embryonic trophoblast cells migrate out from the ectoplacental cone (epc) to form a hybrid vasculature in contact with maternal blood. (B) The trophoblast cells of Ets2 mutant embryos fail to migrate and differentiate, resulting in the characteristic bloody implantation site. (C) A higher magnification of the E6.5 mutant embryo shows a membrane (arrow) covering the ectoplacental cone. (E) At E7.5, the mutant embryo is small and beginning to die. (F) High magnification of the E7.5 mutant shows apoptotic nuclei in embryonic ectoderm (arrow). Scale bars, $125 \mu \mathrm{m}$. Hematoxylin and eosin-stained glycol methacrylate sections.

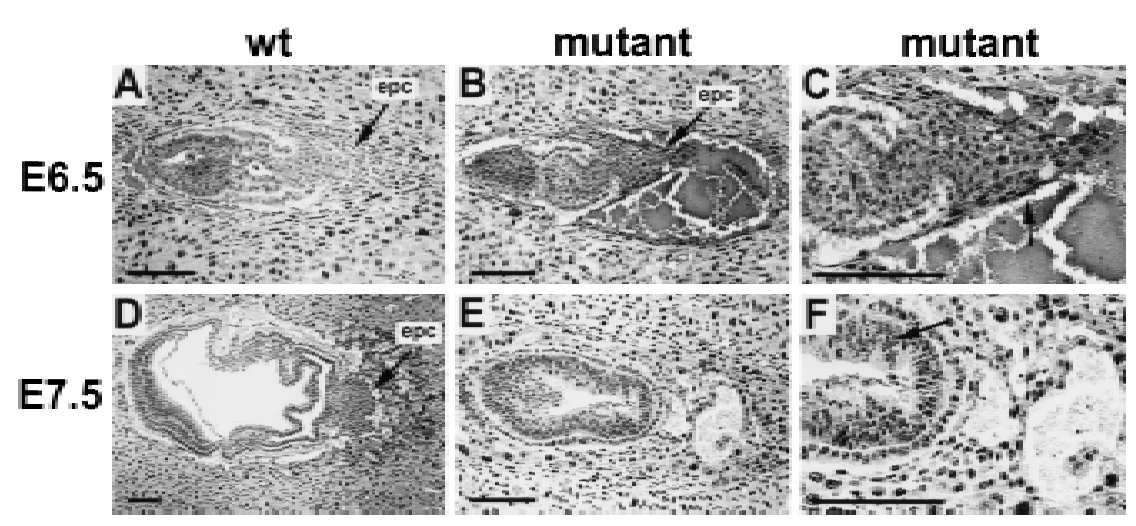




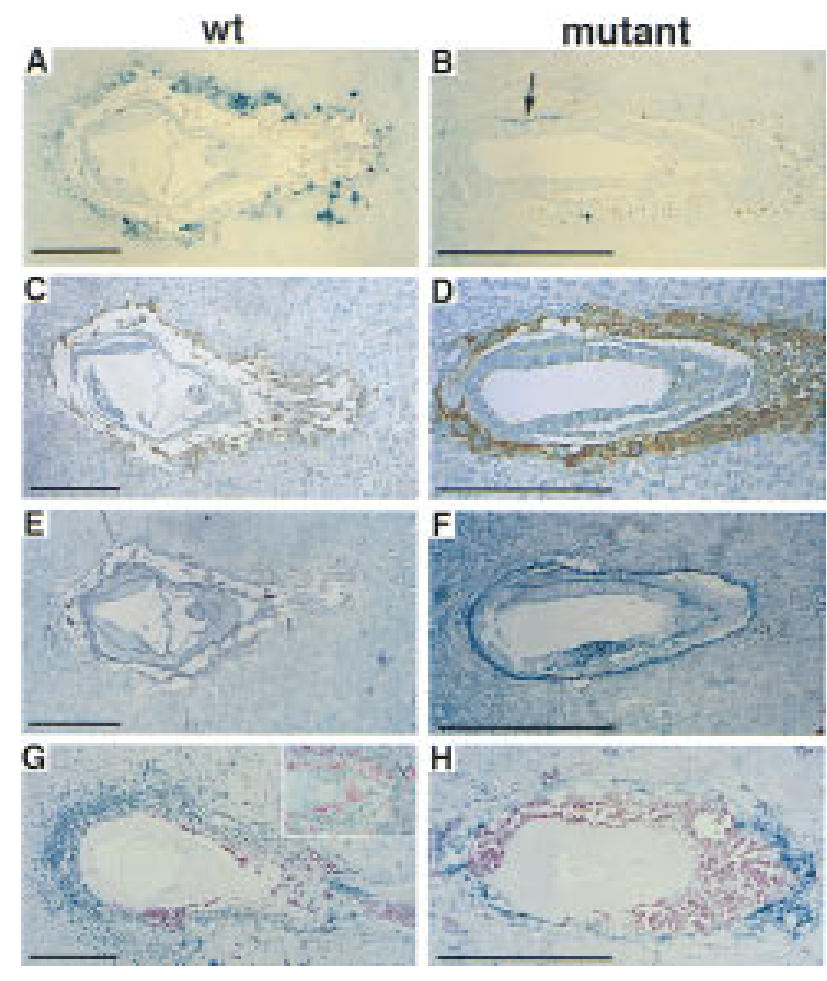

Figure 4. A bnormal protein expression in ets $2^{\mathrm{db} 1 / \mathrm{db} 1}$ embryos at E7.5. (A,B) Tissue-specific regulation of M M P-9 in a mutant embryo. N ote the absence of immunoreactive MMP-9 in the surrounding trophoblast cells of the mutant (B), as compared to wild-type (A), but the area where primitive streak should form shows a positive stain (arrow) with anti-M M P-9. (C,D) Placental lactogen-1 staining is normal in wild-type (C) (brown color), but is substantially upregulated in the mutant embryo (D). (E,F) Anti-laminin staining for basement membranes (blue color) shows extended expression of laminin around the ectoplacental cone. $(\mathrm{G}, \mathrm{H})$ Anti-PECAM antibody to detect endothelial cells of blood vessels (blue color) shows that vascular connections to maternal circulation are severely compromised in the mutant embryo $(\mathrm{H})$, compared to the wild type $(\mathrm{G})$. The higher magnification inset in $G$ shows the staining of ectoplacental cone cells. Primary antibodies were detected with HRP-labeled secondary antibodies, and then histochemical detection for peroxidase. A, B, E, F, G, and $H$ are True Blue substrate with eosin counterstain. $C$ and D are DAB (brown) substrate with methyl green counterstain.

The extraembryonic defects of ets $2^{\mathrm{db} 1 / \mathrm{db} 1}$ embryos are complemented by tetraploid embryos

The second type of cellular rescue experiment utilized embryos from ets $2^{\mathrm{db} 1 /+}$ heterozygotes matings aggregated with tetraploid embryos. Tetraploid embryos are capable of forming normal extraembryonic tissues but do not contribute to the embryonic portion of embryos (N agy et al. 1990). At E14.5, 2 ets2 ${ }^{\mathrm{db} 1 / \mathrm{db} 1}$ homozygous embryos were detected by PCR among 31 embryos resulting from the aggregation of tetrapl oid wild-type embryos and embryos from ets $2^{\mathrm{db} 1 /+}$ parents. One example is shown in Fig. 5A. Although small, it was still within the variation found for normal embryos (compare em- bryos 1 and 6, Fig. 5A). The yolk sac of this ets $2^{\mathrm{db} 1 / \mathrm{db} 1}$ embryo had both the wild-type and targeted Ets2 alleles because of a mixture of wild-type and ets2 ${ }^{\mathrm{db} 1 / \mathrm{db} 1}$ cells (Fig. 5C). Both ets2 $2^{\mathrm{db} 1 / \mathrm{db} 1}$ embryos appeared normal upon histol ogical examination (data not shown). The rescue of these embryos indicates that embryo devel opment can proceed in the absence of normal Ets2 product when functional trophoblast and extraembryonic tissue function is provided.

Adult ets2 ${ }^{\mathrm{db} 1 / \mathrm{db} 1}$ mice display a hair phenotype resembling that of animals with defective signaling through the EGF receptor.

We next al lowed tetraploid embryos aggregated with embryos from ets $2^{\mathrm{dbl} /+}$ heterozygote matings to proceed to term. Of 40 pups, 4 recovered by cesarean section at term were identified as ets $2^{\mathrm{db} 1 / \mathrm{db} 1}$ homozygotes. At birth, ets $2^{\mathrm{db} 1 / \mathrm{db} 1}$ mice were distinguished by curly whiskers. After $\sim 2$ weeks, the ets2 ${ }^{\mathrm{db} 1 / \mathrm{db} 1}$ homozygotes were distinguished by curly whiskers, wavy hair, and slightly rounded forehead (Figs. 5 and 6 ). In adults, all four types of hai (guard hair, awl, auchene, and zi gzag) were abnormally curved (Fig. 6F; data not shown). Whole mount analysis of the skin of the ets2 ${ }^{\mathrm{db} 1 / \mathrm{db} 1}$ animal revealed misaligned hair follicles, resulting in ingrown, curly hairs that failed to penetrate the epi dermal surface (Fig. $6 \mathrm{H})$. Sections of the skin confirmed curved and misaligned hair follicles (Fig. 6) ). However, the dorsal epidermis of adults was of normal morphology, and the internal morphology of the hair follicles was indistinguishable from normal heterozygote or wild-type littermate controls. These abnormalities of whiskers, hair, and hair follicles closely resemble the phenotype of TGF $\alpha$-deficient animals (Luetteke et al. 1993; M ann et al . 1993) and of mice with a point mutation of the EGF receptor (EGFR) (Luettke et al. 1994). Two ets2 ${ }^{\mathrm{db} 1 / \mathrm{db} 1}$ mice developed eye irritations (Fig. 6D) that resolved spontaneously. Eye abnormal ities are al so characteristic of some, but not all TGF $\alpha$-null mice (Luetteke et al. 1993; Mann et al. 1993). However, unlike some of the TGF $\alpha$ knockout mice, which were born with open eyes, all ets2 $2^{\mathrm{db} 1 /}$ db1 newborns had normal closed eyes. The subtle differences in head morphology characteristic of rescued ets $2^{\mathrm{db} 1 / \mathrm{db} 1}$ mice were not reported for TGF $\alpha$-null mice. Whereas the heads of these rescued mice were distinguishable from their littermates, no differences in skull skel etal structure was detected (data not shown). Thus, the differences in appearance of the head are likely caused by muscle or skin differences.

One male and one female rescued-ets $2^{\mathrm{db} 1 / \mathrm{db} 1}$ mouse generated progeny upon subsequent mating. Thus both sexes are fertile. Other major organs of two adult ets2 ${ }^{\mathrm{db} 1 /}$ db1 mice did not reveal abnormalities upon macroscopic and microscopic examination (data not shown). To assess lymphoid and myeloid cell development in the ets $2^{\mathrm{db} 1 / \mathrm{db} 1}$ mouse, spleen cells of adult mice were treated with fluorescent conjugates of 16 different monoclonal antibodies (see Materials and M ethods) and analyzed by flow cytometry. In all cases, T cell, B cell, and 
Figure 5. Rescue of ets $2^{\mathrm{db} 1 / \mathrm{db} 1}$ embryos by aggregation with tetraploid embryos. (A) E14.5-day embryos resulting from the aggregation with wild-type tetraploid embryos. (B) PCR analysis of the embryos reveals that embryo 1 is homozygous mutant, whereas embryos 3 and 4 are heterozygous and 2, 5, and 6 are wild-type. (C) PCR analysis of the yolk sac DNA. The equal intensity of the amplified bands of sample 1 indicates approximately equal contribution of wild-type and targeted cells to the yolk sac. (D,F) Three-week-old wild-type mice resulting from a tetraploid embryo aggregation experiment. (E,G) Rescued ets $2^{\mathrm{db} 1 / \mathrm{db} 1}$ mouse. $\mathrm{N}$ ote the wavy
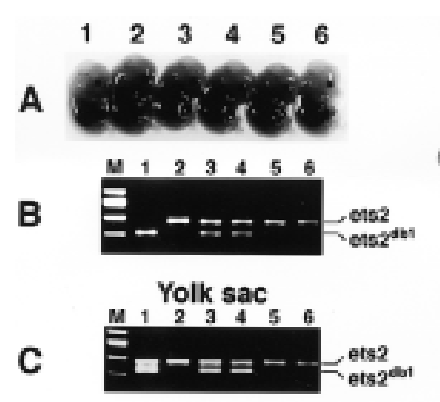

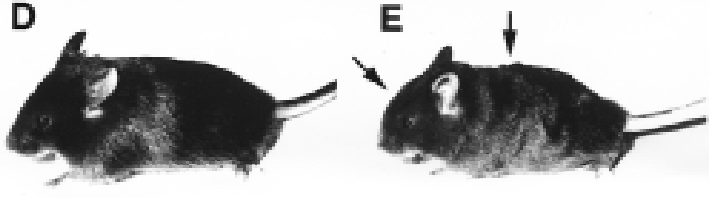

$\mathbf{F}$
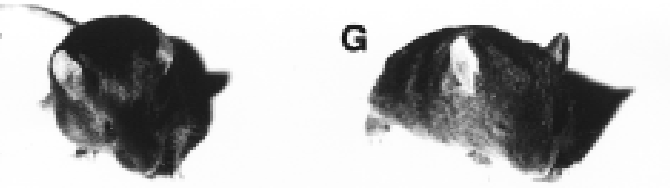

myel oid surface marker profile of the ets2 ${ }^{\mathrm{db} 1 / \mathrm{db} 1}$ spl een cells was similar to that of normal mice.

The mitogenic responses of T cells, B cells, and macrophages from the ets $2^{\mathrm{db} 1 / \mathrm{db} 1}$ mouse were assessed as well. Spleen cells were treated with ConA, anti-CD3, and LPS. No difference in the rates of proliferation were seen between the ets $2^{\mathrm{db} 1 / \mathrm{db} 1}$ and normal $T$ and $B$ cells following any of the treatments. Although Ets2 has been implicated as a mediator of mitogenic signals from the M-CSF receptor, we were able to culture and expand bone marrow macrophages from ets $2^{\mathrm{db} 1 / \mathrm{db} 1}$ mouse in M-CSF-containing medium. To measure their ability to be activated, these macrophages and macrophages cultured from normal mice were treated with either interferon $\gamma$ (IFN- $\gamma)$, LPS or IFN $-\gamma+$ LPS, and assayed by flow cytometry for the increased expression of IFN - $\gamma$ receptor, MHC class II antigen I-Ab, and scavenger receptor. In response to these treatments, all assayed antigens in the ets $2^{\mathrm{db} 1 / \mathrm{db} 1}$ macrophages were expressed at equivalent levels to that seen in macrophages from normal mice. We conclude that no major defect in either lymphocytes or macrophages occurs in mice that lack wild-type Ets2. With regard to macrophages, these results confirm our earlier analysis of macrophages generated in vitro from the differentiation of doubly targeted ES cells (Henkel et al. 1996).

Both TGF $\alpha$ and EGFR are expressed in ets $2^{\mathrm{db} 1 / \mathrm{db} 1}$ mice

Because rescued ets $2^{\mathrm{db} 1 / \mathrm{db} 1}$ animals resembled animals with defective EGFR or its ligands, we examined the expression of TGF $\alpha$ and EGFR. TGF $\alpha$ protein, assessed by radioimmuno assay, was not distinguishable from normal adult kidney (wild type, $7 \mathrm{pg} / \mathrm{mg}$ total protein; ets $2^{\mathrm{db} 1 / \mathrm{db} 1}, 6.8 \mathrm{pg} / \mathrm{mg}$ total protein ) and was $50 \%$ or greater of the wild-type level in the skin of the adult ets $2^{\mathrm{db} 1 / \mathrm{db} 1}$ mouse (wild type, $3.5 \mathrm{pg} / \mathrm{mg}$ total protein; ets2 $2^{\mathrm{db} 1 / \mathrm{db} 1}, 2 \mathrm{pg} / \mathrm{mg}$ total protein). TGF $\alpha$ and the EGFr mRNAs in skin and liver of the ets2 $2^{\mathrm{db} 1 / \mathrm{db} 1}$ mouse were at normal levels (Fig. 7A).
Altered expression of MMP-3, 9, and 13 in adult ets $2^{\mathrm{db} 1 / \mathrm{db} 1}$ tissues

Ets factors regulate many genes. RN A transcripts for the candidate target genes $p 53$, endo $A$, endo $B$, junB, HNF4 , and ets1 were not affected by the absence of Ets2 in kidney, lung, liver, heart, and brain of the rescued adult (Fig. 7A). However, MMP-3, MMP-9, uPA, and ets1 were all lower in skin samples for homozygous and heterozygous animals (Fig. 7A), when normalized to L32 RNA levels (Fig. 7B). In contrast, ets1, MMP-3, MMP-9, and UPA RNAs were at similar levels in the mammary glands of wild-type, ets2 $2^{\mathrm{db} 1 /+}$, and ets2 $2^{\mathrm{db} 1 / \mathrm{db} 1}$ mice (Fig. 7B). MMP-13 was al so lower in ets $2^{\mathrm{db} 1 / \mathrm{db} 1}$ lung and intestine (Fig. 7A). Tissue specificity in M MP-9 expression was noted in the E7.5 ets $2^{\mathrm{db} 1 / \mathrm{db} 1}$ embryos, which downregul ated this enzyme in trophobl ast, yet maintained expression in the primitive streak (Fig. 4B). These data indicate that there is tissue specificity in the effects of wild-type Ets2 on the expression of MMP-3, MMP-9, and MMP-13.

ets2 ${ }^{\mathrm{db} 1 / \mathrm{db} 1}$ cells are defective in the induction of MMP-13 and MMP-3 RNAs by FGF2

To explore the role of Ets2 in mediating growth factor signal ing, we established a fi broblastic cell line from primary cultures of teratocarcinoma tumors formed by the subcutaneous injection of the ets2 ${ }^{\mathrm{db} 1 / \mathrm{db} 1}$ ES cells. One cell line, which lacked wild-type Ets2 expression, was subsequently transfected with an expression vector for Ets2 or empty expression vector and multiple clones were isolated. Several rescued clones that expressed moderate levels of Ets2 were compared with the parental cell line for gene expressi on after growth factor exposure. The parental EKO1 line and the E8 and E13 Ets2 rescued clones responded equally to mitogenic stimulation by FGF1, FGF2, EGF, and TGF $\alpha$, as analyzed by $\left[{ }^{3} \mathrm{H}\right]$ thymidine incorporation at $24 \mathrm{hr}$, and grew at comparable rates in media containing fetal bovine serum. However, serum-starved EKO1 cells (Fig. 8) expressed little MMP-3 

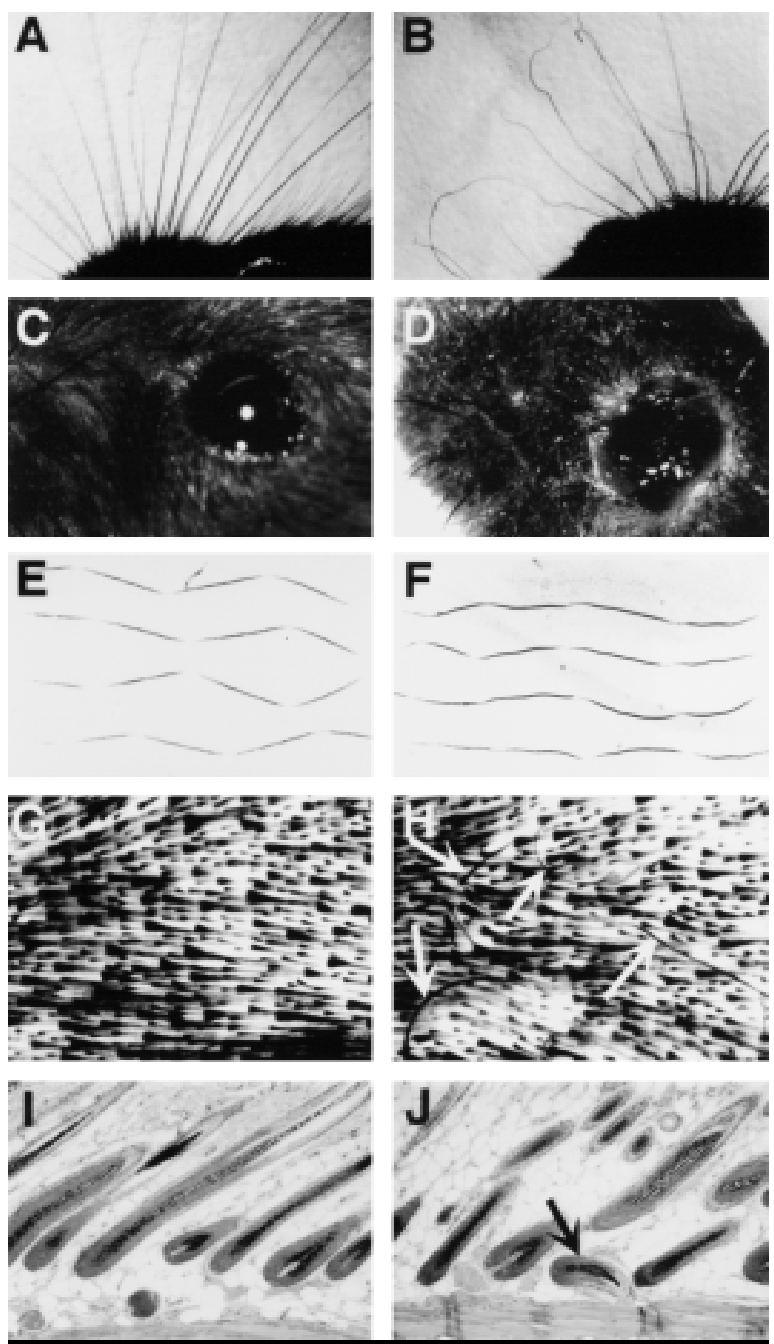

Figure 6. Phenotype in whiskers, hair, and eye al teration of the ets2 ${ }^{\mathrm{db} 1 / \mathrm{db} 1}$ adult mouse. (A,C,E, G,I) Wild-type mouse whiskers, eye, zigzag hair, whole mount skin, and hair follicle histology respectively; $(B, D, F, H, J)$ from ets $2^{d b 1 / d b 1}$ mouse. (D) Eye secretions of the ets $2^{\mathrm{db} 1 / \mathrm{db} 1}$ mouse were transient and resolved spontaneously without treatment within a few weeks. (H) Arrows point to ingrown hairs lying wholly within the skin. View is from the lower part of the cleared skin in $G$ and $H$. () Arrow points to abnormally oriented hair follicle. $\mathrm{N}$ ote the unusual juxtaposition directly against the lower muscle layer of the skin.

or MMP-13 RNA, and exposure to FGF2 failed to induce the RNA. Treatment of Ets2 expressing subclones with growth factors increased MMP-13 and MMP-3 RNAs within $7 \mathrm{hr}$, whereas RNAs for the L32 ribosomal protein, Ets1, type IV and type I collagens (not shown) were relatively insensitive to serum starvation and growth factor treatment. RN As for cJun and UPA were increased by exposure to FGF2, independent of Ets2 expression. In contrast, TGF $\alpha$ did not induce either MMP-13 or MMP-3 RNAs in any of the three cell lines. These results show that the ets $2^{\mathrm{db} 1 / \mathrm{db} 1}$ EKO1 cell line is deficient in the induction of both MMP-13 and MMP-3 in response to
FGF2. However, MMP-3 deficiency is probably not the key target gene responsible for either the trophoblastic defects or the hair growth abnormalities, because a MMP-3 knockout mouse is viable and does not have curly hair. However preliminary anal yses of MMP-9-targeted embryos suggests that some of the trophoblastic defects of ets2 ${ }^{\mathrm{db} 1 / \mathrm{db} 1}$ embryos may be a direct consequence of MMP-9 deficiency ( $Z$. Werb, unpubl.).

\section{Discussion}

Ets2 is essential for ectoplacental cone proliferation and the establishment of vascular interactions with the maternal circulation. The targeting of Ets 2 leads to deficient maternal nutrition, impaired growth, and the eventual death of the embryonic ectoderm by apoptosis. The failure of gastrulation contributes to the absence of amnion and chorion membranes but appears to occur after the beginning of the primitive streak (Fig. 4B). Targeted mutagenesis of a large number of genes result in placentation failures (Copp 1995). A mong these, tetraploid embryo aggregation has successfully rescued homozygous mutations of Mash-2 (Guillemot et al. 1994), a trophoblast-specific transcription factor, ERR- $\beta$, an orphan hormone receptor (Luo et al. 1997) and the AP-1 transcription factor JunB (Erwin Wagner, pers. comm.). The abnormalities of embryonic ectoderm apoptosis and gastrulation of ets $2^{\mathrm{db} 1 / \mathrm{db} 1}$ embryos resemble the effects of targeting the HNF4 transcription factor, which are also similarly complemented by aggregation with tetraploid embryos (Chen et al. 1994; Duncan et al. 1997). However, we did not detect al terations in HN F4 expression in either differentiating ets $2^{\mathrm{db} 1 / \mathrm{db} 1}$ ES cells or adult rescued mice. The extraembryonic defects seen in the ets $2^{\mathrm{db} 1 / \mathrm{db} 1}$ embryos appear different from other placental abnormalities resulting from gene targeting. The failure of ectoplacental cone proliferation, the increased placental lactogen expression, and the complete resorption of the ets $2^{\mathrm{db} 1 / \mathrm{db} 1}$ embryos by E8.5 are distinctive.

Both TGF $\alpha$ and FGF5 have been implicated in the regulation of hair growth (Hebert et al . 1994). The abnormalities in hair development, including curly whiskers and hair, misaligned hair follicles and ingrown hairs of the rescued ets $2^{\mathrm{db} 1 / \mathrm{db} 1}$ mice, resemble the phenotype of TGF $\alpha$-null animals (Luetteke et al. 1993; Mann et al. 1993) or the spontaneous waved-1 mutation of the TGF $\alpha$ gene (Berkowitz et al. 1996). However, the hair abnormalities of the ets $2^{\mathrm{db} 1 / \mathrm{db} 1}$ mice were not caused by TGF $\alpha$ or EGFR deficiency. Moreover, ets $2^{\mathrm{db} 1 / \mathrm{db} 1}$ fibroblast cell lines responded mitogenically to EGF and TGF $\alpha$.

Ets2 may mediate ei ther TGF $\alpha$ or FGF signaling during embryonic hair foll icle devel opment (Hardy 1992) by the regulation of a subset of growth-factor-regulated genes. Clearly, Ets2 does not mediate all such signaling by either type of growth factor because the phenotypes of mice with targeted mutations of different FGFs, EGF, $\mathrm{TGF} \alpha$, and their receptors are distinct from those found in rescued ets $2^{\mathrm{db} 1 / \mathrm{db} 1}$ mice (M iettinen et al. 1995; Sibilia and Wagner 1995; Threadgill et al. 1995; Yamaguchi and 
Yamamoto et al.

Figure 7. RN ase protection analysis of adult organ RNAs. (A) All RN As were from male 90-day-old tetraploid embryo aggregation littermates except for brain and mammary gland samples of heterozygous and homozygous 50-day littermate females of a second tetraploid embryo aggregation experiment. The wild-type female mammary gland and brain samples were from a 90-day-old adult. Twenty or $10 \mu \mathrm{g}$ (c-Jun, EGFr, Endo A, and Endo B) of total RNA from the indicated organs was analyzed by RN ase protection with probes indicated at right. Protected fragments were resolved by acrylamide gel electrophoresis and detected by autoradiography in the presence of enhancer screens and quantified using a Phosphorlmager. Images are from autoradiographic exposures of five different gels, each of which also contained L32 signals (additional data shown). Signals for uPA (lanes 4-9), HNF4, HNF3 $\beta$ (Ianes 4-6) and EGFr, endo A, and endo B (lanes 16-18) are 1-day exposures for improved clarity. (B) Quantitation of ets1, MMP-3, MMP-9, UPA, and junB mRNA after normalization to L32 RNA in skin and mammary gland samples.

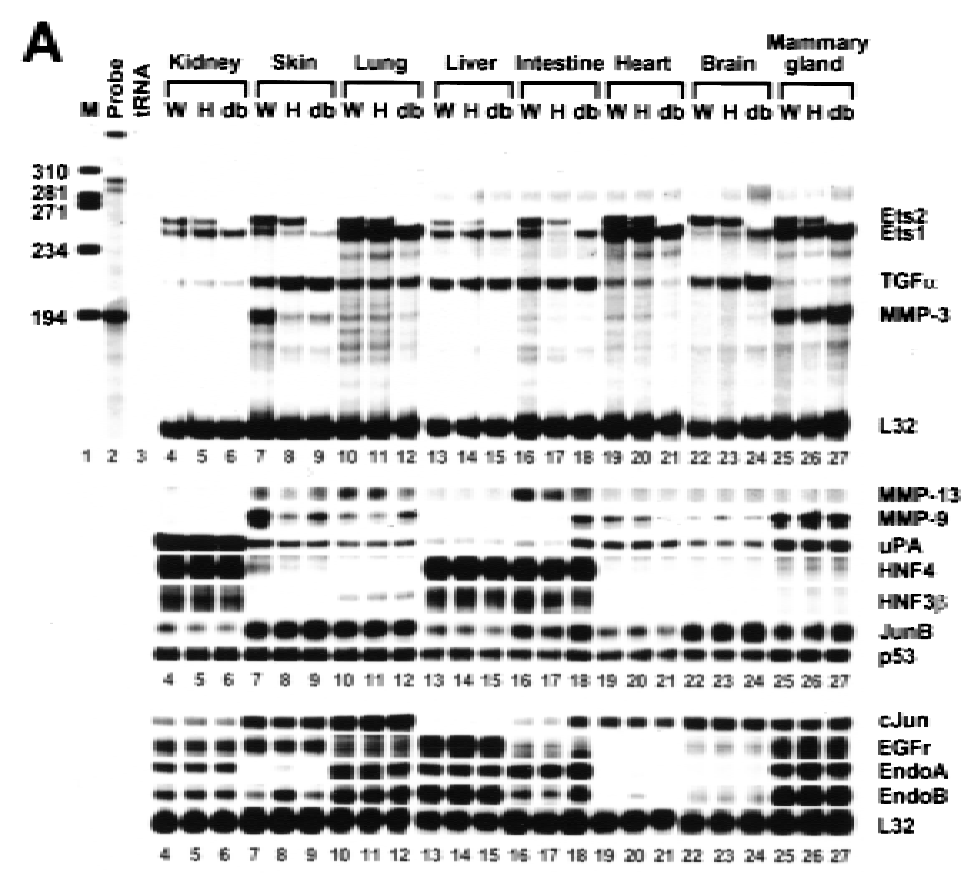

B

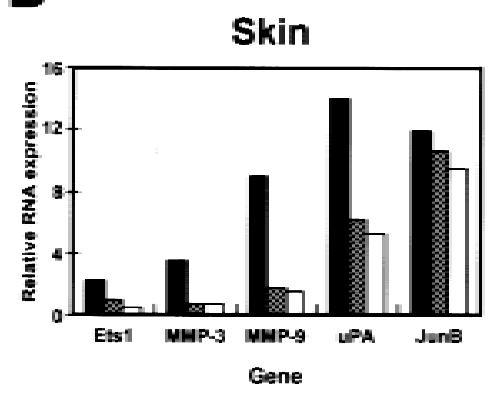

Rossant 1995). However, Ets family members have been implicated in mediating FGF and EGF signaling through ras signal transduction pathways in Drosophila, C. elegans, and mammals (Ghysdael and Boureux 1997).

In the light of the widespread expression of Ets2 (Maroulakou et al. 1994), the mild effect of targeting Ets2 on the development of rescued mouse embryos was surprising. In contrast to the key roles of the PU.1 and Ets1 members of the Ets family in the immune system (Boulukos et al. 1990; Scott et al. 1994; Muthusamy et al. 1995; McKercher et al. 1996), Ets2 does not appear essential for lymphoid cells. In part, this result confirms the earlier study of Ets2-deficient macrophages generated in vitro from doubly targeted ES cells (Henkel et al. 1996).

Ets family transcription factors have been strongly implicated in the regulation of human MMP-1 (mouse MMP-13) (Gutman and Wasylyk 1990; Logan et al. 1996), rat MMP-3 (Wasylyk et al. 1991), and human MMP-9 (Gum et al. 1996). Thus, the misregulation of these MMPs may be a direct consequence of the absence of wild-type Ets2. Some of the placental and extraembryonic endodermal defects of ets $2^{\mathrm{db} 1 / \mathrm{db} 1}$ embryos may reflect a particular importance of Ets2 for proteases that act on extracellular matrix. MMP-9 was poorly expressed in the trophoblast cells of implanting ets $2^{\mathrm{db} 1 / \mathrm{db} 1} \mathrm{em}$ bryos, and the unusual persistence of the Reichert's membrane may reflect the failure of appropriate remodeling of this extracellular matrix. Similarly, ets $2^{\mathrm{db} 1 / \mathrm{db} 1}$ fibroblast cells fail to express both MMP-13 and MMP-3 in response to growth factor exposure unless exogenous Ets2 is supplied. Two tandem, inverted Ets binding sites of the MMP-3 promoter are responsible for Ets factor responsiveness, and a model of this site has been shown to be particularly sensitive for Ets2 transactivation (Gal ang et al . 1994). However, the dependence of M M P-3 and M M P-9 on Ets2 is cell-type dependent. The levels of MMP-3 RNA were normal in adult ets $2^{\mathrm{db} 1 / \mathrm{db} 1}$ mammary gland but markedly reduced in skin. Similarly, MMP-9 was normal in lung and mammary gland but absent in ets $2^{\mathrm{db} 1 / \mathrm{db} 1}$ trophoblast of mice. Multiple factors, such as AP-1, are important for optimal expression of each of these genes in particular cell types (M CDonnell and Matrisian 1990; Bortner et al. 1993; Wasylyk et al. 1993; Ghysdael and Boureux 1997). Our data indicate that the same gene utilizes different specific transcription factors in different tissues.

Matrix metalloproteinases are important for the re- 
A

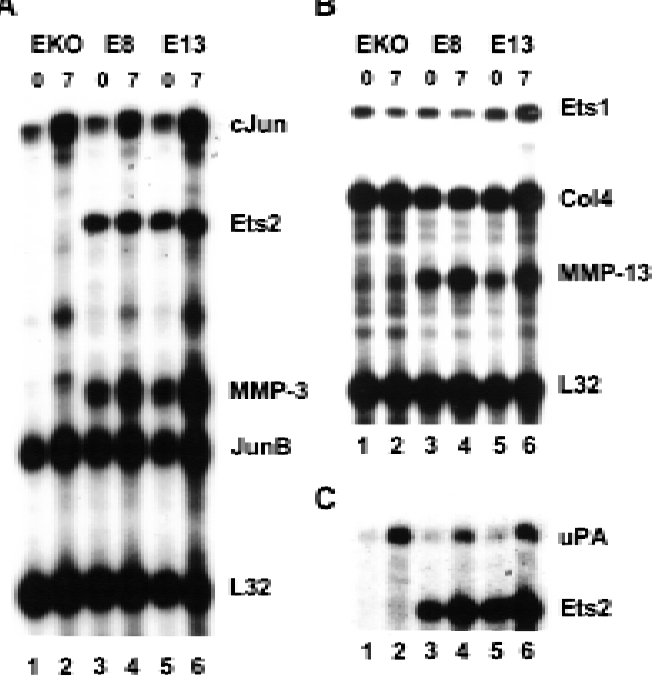

Figure 8. Role of Ets2 in FGF2 induction of MMP-13 and M MP-3 in cultured cells. The EKO1 Ets2-deficient fibroblastic cell line and two independent isolates that expressed transfected Ets2 (E8 and E13) were incubated in medium containing $0.5 \%$ fetal bovine serum for 2 days. FGF2 $(50 \mathrm{ng} / \mathrm{ml})$ was added for $7 \mathrm{hr}$ and RNA was isolated. The indicated RN As were detected by RN ase protection analysis. Collagen IV is indicated by Col4. Shown are autoradiographic exposures of the acrylamide gels used to separate the protected fragments. The time of growth factor exposure is indicated in hours at the top of each lane. $\mathrm{N}$ ote the increased expression of the M M P-3 (A, lanes 3,5$)$ ) and M M P-13 (B, lanes 3,5) RN As in the E8 and E13 cell lines and their further increase after $7 \mathrm{hr}$.

modeling of extracellular matrix, and are involved in normal organ devel opment and the invasive behavior of both normal and tumor cells (McDonnell and Matrisian 1990; Sympson et al. 1994, 1995). A large number of genes have been identified as potential targets of Ets factor regulation (Ghysdael and Boureux 1997). It is now clear that Ets2 is limiting for expression of only a subset of these genes and in particular tissues. The sensitivity and specificity of MMP-13, MMP-3, and M MP-9 gene expression to the levels of Ets2 in certain tissues suggests that targeting specific transcription factors could have very selective effects on the expression of these proteinases in normal tissues and during disease processes. Viable transcription factor knockout mice, coupled with large-scale expression studies, may eventually provide the basis for devel oping predictive models of tissue-specific, target gene expression.

\section{Materials and methods}

\section{Gene targeting of ets2}

The construction of the ets2 targeting vector, the isolation of targeted D3 ES cells, and the generation of ES cells with two targeted alleles have been described previously (Henkel et al. 1996). Four independently targeted clones were injected into strain C 57/BI 6 mouse blastocysts by standard methods (Stewart and M intz 1981; Hogan et al. 1986). A single founder chimera transmitted the mutant allele to subsequent generations of Swiss Black and 129/Sv strains of mice.

\section{Cell line isolation}

Differentiated ets $2^{\mathrm{db} 1 / \mathrm{db} 1}$ cell lines were isolated from teratocarcinomas formed by the injection of ets2 $2^{++}$, ets $2^{\mathrm{db} 1 /+}$, and ets $2^{\mathrm{db} 1 / \mathrm{db} 1}$ ES cells into strain 129 Sv mice (Oshima et al. 1981). The EKO1 ets2 ${ }^{\mathrm{db} 1 / \mathrm{db} 1}$ fibroblastic cell line was established by repeated selection for rapid attachment to plastic culture dishes and low-density growth in the absence of LIF. The fibroblastic cell derivative was cloned twice after establishment. This line was subsequently transfected with an expression vector for Ets2 which al so contains a FLAG epitope tag and a synthetic nuclear localization signal fused to the amino' terminus (FNets2) (Gal ang et al. 1996). FN ets2 was expressed from a derivative of the pCIN 4 vector (Rees et al. 1996) in which the neo-selectable gene was replaced with the hygromycin gene to generate $\mathrm{pCIH}-$ FN ets2. Thirteen independent clones with varied Ets2 expression were isolated. The E8 and E13 clones were representative of those with moderate levels of ets2 RNA.

\section{Growth factor treatment}

Growth factor induction of DNA synthesis was measured as described (M ohammad et al. 1996) except for the use of medium containing $0.5 \%$ fetal bovine serum for starvation. FGF1, FGF2, EGF, or TGF $\alpha$ concentrations ranged from 0.03 to $100 \mathrm{ng} / \mathrm{ml}$. For RN A analysis, 6- or 9-cm dishes of the indicated cell types were subjected to serum starvation ( $0.5 \%$ fetal bovine serum) for $48 \mathrm{hr}$ and then exposed to FGF $(50 \mathrm{ng} / \mathrm{ml})$, EGF $(10 \mathrm{ng} / \mathrm{ml})$, or TGF $\alpha(10 \mathrm{ng} / \mathrm{ml})$ for 7 or $24 \mathrm{hr}$. RN A was prepared from the cells with the use of acidic phenol (RN Azol) (Chomcznski and Sacchi 1987).

\section{Protein analysis}

Cells were labeled by incubation with $500 \mu \mathrm{Ci} / \mathrm{ml}\left[{ }^{35} \mathrm{~S}\right]$ methionine in methionine-free medium containing $10 \%$ dialyzed fetal bovine serum for $1 \mathrm{hr}$. Cell lysates were prepared as previously described (Oshima 1981) or in RIPA buffer with similar results. Lysates were precleared with nonimmune rabbit serum and protein A-Sepharose (Pharmacia) and then incubated with $3 \mu \mathrm{l}$ of rabbit anti-mouse Ets2 antiserum. The antiserum was prepared by immunization of a rabbit with a purified Tryp-E Ets2 fusion protein expressed in bacteria (McCarthy et al. 1997). Reactive proteins were recovered and analyzed as described previously (Oshima 1981) except Protein A-Sepharose instead of formal infixed Staphlyococus aureus was used and washes were performed in lysis buffer. For cell fractionation experiments, labeled cells were recovered by scraping in $10 \mathrm{~mm}$ Tris- $\mathrm{HCl}(\mathrm{pH}$ 7.4), $3 \mathrm{~mm}, \mathrm{MgCl}_{2}, 0.1 \mathrm{~mm}, \mathrm{CaCl}_{2}, 50 \mathrm{~mm} \mathrm{KCl}, 0.1 \% \mathrm{NP}-40$ detergent, $1 \%$ aprotinin solution, $1 \mathrm{~mm}$ pepstatin, $1 \mathrm{~mm}$ leupeptin. After homogenization or vigorous vortex mixing, the nuclear/cytoskeletal and supernatant (cytoplasmic) fractions were recovered by centrifugation at $5000 \mathrm{~g}$ for $5 \mathrm{~min}$. The DNA of the nuclear fraction was digested briefly with DN ase I, then both fractions were adjusted to $5 \mathrm{~mm}$ EDTA, $0.1 \%$ SDS, heated to $100^{\circ} \mathrm{C}$ for $3 \mathrm{~min}$, cool ed, and adjusted to $0.5 \% \mathrm{~N} \mathrm{P}-40$. Lysates were stored frozen at $-80^{\circ} \mathrm{C}$ and cleared by centrifugation at $12,000 \mathrm{~g}$ for $20 \mathrm{~min}$ before use.

\section{PCR analysis}

Genomic DNA was prepared from ES cells, embryos, and tails by incubation in $0.45 \%$ NP-40, 0.45\% Tween 20, 10 mM Tris$\mathrm{HCl}(\mathrm{pH} 8.3), 3 \mathrm{mM} \mathrm{M} \mathrm{gCl}_{2}$, and $0.1 \mathrm{mg} / \mathrm{ml}$ proteinase $\mathrm{K}$ at $56^{\circ} \mathrm{C}$ (Zeitlin et al. 1995). Lysates were used for PCR after inactivation of the proteinase $\mathrm{K}$ at $96^{\circ} \mathrm{C}$ for $10 \mathrm{~min}$ and centrifugation. Alternatively, DNAs were purified by standard protease $\mathrm{K}$ digestion in the presence of SDS and phenol-chloroform extraction. Three primers, E163 (CGTCCCTACTGGATGTACAG- 
CGG), E361 (TGCTTTGGTCAAATAGGAGCCACTG), and EN 3 (AATGACAAGACGCTGGGCGG) were used in a 20- $\mu$ l reaction containing $3 \mathrm{~mm} \mathrm{M} \mathrm{gCl}_{2}, 1 \mathrm{~mm}$ deoxynucleotide triphosphates and 0.5 units of Taq polymerase. The cycling conditions were $94^{\circ} \mathrm{C}$ for $5 \mathrm{~min}$ followed by $35 \mathrm{cycles}$ of $94^{\circ} \mathrm{C}$ for 30 $\mathrm{sec}, 70^{\circ} \mathrm{C}$ for $30 \mathrm{sec}$, and $72^{\circ} \mathrm{C}$ for $45 \mathrm{sec}$. The E163 and E361 primers are specific for ets 2 gene. The EN 3 primer is specific for the neo gene.

\section{RNA analysis}

RN ase protection assays were performed as described previously (N eznanov and Oshima 1993). The probes were synthesized from either pGEM 1, Bluescript KS, or SP64 vectors containing the indicated fragments of the following mouse CDN As: ets2, GenBank accession number J04103, bp 1056-1312; Ets1, X53953, bp 620-897 (gift from Barbara Graves, University of Utah, Salt Lake City); collagen IV, J04694, bp 4454-4734; collagen a1(I), K01688, bp 1-335 [gift from Michael Breindl (Rippe et al. 1989)]; stromelysin-1, X63162, bp 1187-1381, (gift of Lynn Matrisian, Vanderbilt University, Nashville, TN), c-jun, X12740, bp 406-713, (gift of Yukio N ishina, Yokohama City University, Japan); junB, J03236, bp 272-455 (gift of Daniel $\mathrm{N}$ athans, Johns Hopkins U niversity, Bal timore, MD); gel atinase B (MMP-9) Z27231, bp 1935-2258, derived from pSP65 92b (Reponen et al. 1994); HNF-4, D29015, bp 628-819 (gift of Shingo Hata, Kyoto University, Japan); HNF3- $\beta$, X74937, bp 987-1152 (gift of Kenneth Zaret, Brown University, Providence, RI); urokinase plasminogen activator (UPA), X02389, bp 652-833 (gift of Dominique Belin, Centre Medical Universitaire, Geneva, Switzerland); collagenase-3 (M MP-13), X66473, bp 699-872 (gift of Peter Angel, Kernforschungszentrum Karlsruhe, Karlsruhe, Germany) [previously referred to as collagenase-1 (Gack et al. 1994)]; TGF $\alpha$, U 65016, bp 416-625; and EGFr, X59698, bp 15721763. The TGF $\alpha$ and EGFr fragments were obtained by RT-PCR of $2 \mu \mathrm{g}$ of total mouse kidney RNA.

\section{Whole-mount in situ hybridization}

For whole-mount in situ hybridization to anal yze plasmids containing 900 bp of 3' UTR upstream of the ets2 poly(A) tail or Brachyury (Hermann 1991) were linearized. Antisense digoxigenin riboprobes were prepared using digoxigenin-dUTP (Boehringer $\mathrm{M}$ annheim) and the manufacturer's conditions. These were used to probe E6-E7.5 embryos using a previously described protocol (Henrique et al. 1995). Staining times varied from a few hours to overnight.

\section{Immunocytochemistry}

Sections of paraformal dehyde-fixed and paraffin-embedded embryos were incubated with polyclonal rabbit anti-mouse M MP9/gelatinase B antibody (Behrendtsen et al. 1992), monoclonal rat anti-mouse PECAM-1 antibody (Vecchi et al. 1994), antilaminin antibody (Collaborative Research Co.), or rabbit antimouse placental lactogen-1 (gift of D. Linzer, Northwestern University, Evanston, IL), essentially as described previously (Alexander et al. 1996; Behrendtsen and Werb 1997), by horseradish peroxidase-label ed secondary antibodies and then developed, using the True Blue reagent (KRL) according to the manufacturer's instructions, or with diaminobenzidine substrate. The sections were counterstained with eosin or methyl green.

\section{Chimera analysis}

Ets2 ${ }^{\mathrm{db} 1 / \mathrm{db} 1}$ ES cells were injected into C $57 / \mathrm{BI} 6$ blastocysts and returned to foster mothers. Five of 11 embryos recovered at E18.5 were found to contain ES cell contribution by glucose phosphate isomerase isozyme analysis (Hogan et al. 1986).

\section{Tetraploid embryo rescue}

Superovulated CD-1 females were mated with FVB/N males. E1.5 embryos at the two-cell stage were flushed from the oviducts and collected in M 2 medium. After equilibration in fusion solution ( $0.3 \mathrm{~m}$ mannitol, $0.1 \mathrm{~mm} \mathrm{MgSO}_{4}, 50 \mathrm{~mm} \mathrm{CalCl}, 3 \%$ bovine serum al bumin) (Duncan et al. 1997), the embryos were placed between the electrodes of a BTX 2001 electro cell manipulator (Genetronics, Inc.), aligned in a $0.6-\mathrm{V} \mathrm{AC}$ field and treated with a single $100-\mathrm{msec}$ DC pulse of $1.3-1.5 \mathrm{kV} / \mathrm{cm}$. The embryos were transferred to microdrops of KSOM medium under mineral oil and incubated at $37^{\circ} \mathrm{C}$ for $30-60 \mathrm{~min}$, at which time successfully fused embryos were selected for overnight culture. The afternoon of the next day, four-cell-stage tetraploid embryos were use for aggregation.

Diploid E2.5 embryos at the six- to eight-cell state were isolated just before use from the oviducts and uterine horn of ets $2^{\mathrm{db} 1 /+}$ females mated with ets $2^{\mathrm{db} 1 /+}$ males. Zonae pellucida in both diploid and tetraploid embryos were removed in acidic Tyrode's solution ( $\mathrm{pH}$ 2.5). Prior to aggregation, the embryos were decompacted by incubation in cal cium-free $M 2$ medium at $37^{\circ} \mathrm{C}$ for $5 \mathrm{~min}$. Two tetraploid embryos were aggregated with one di pl oid embryo using the "darning needle" technique ( $\mathrm{N}$ agy et al. 1990; Duncan et al. 1997; Luo et al. 1997). After 24-26 hr of incubation, successfully aggregated embryos formed single blastocysts that were transferred to the uterine horn of day 2.5 pseudopregnant CD-1 recipients. Some recipients were sacrificed at E14.5 for analysis of embryonic and extraembryonic tissues. Other groups of recipients were subjected to cesarean section at E18.5 (Hogan et al. 1986). Viable fetuses were fostered by females who had delivered litters on the same day.

\section{Flow cytometry}

Cell surface fluorescence was determined essentially as described (McKercher et al. 1996). Fluorescein isothyocyanate (FITC)- or phycoerythrin (PE)-labeled antibodies were previously described or purchased from PharM ingen (San Diego, CA), BioSource (Camarillo, CA) or Harlan Bioproducts for Science (Indianapolis, IN ). T-cell markers were CD4, CD8, CD5 (53-7.3, PharMingen) and CD90 (HIS51, PharMingen). B-cell markers were CD 19 (1D3, PharM ingen), I-Ab (C3H, PharM ingen), IgM (G53-238, PharM ingen), and B220. M yel oid markers were sialoadhesin (3D6.112, BioSource), F4/80, CD11b, MOMA-2 (HarIan), FC $\gamma$ receptor III/II (CD 32/CD16) (2.4G2, PharMingen), scavenger receptor (2F8, Harlan), and GRI.

\section{Acknowledgments}

All embryo aggregation experiments were performed by the M ouse Genetics Shared Service of the Burnham Institute. We thank Jacquiline Avis and Grace Cecena for expert technical assistance, E. Dejana and D. Linzer for antibody gifts, C. Hauser for Ets2 antiserum, recombinant protein, multiple Ets2 constructions, and stimulating discussions. We are al so grateful for advice from A. Nagy on the tetraploid embryo aggregation method. This work was supported by grants from the $\mathrm{N}$ ational Institutes of Health (HD 26732 to Z.W., Al 20656 to R.A.M.), the National Cancer Institute, (CA42302 and CA74547 to R.G.O. supporting the targeting of ES cells and subsequent analysis of the mice respectively) and the Burnham Institute Cancer Center support grant (P30 CA30199).

The publication costs of this article were defrayed in part by payment of page charges. This article must therefore be hereby marked "advertisement" in accordance with 18 USC section 1734 solely to indicate this fact. 


\section{References}

Alexander, C.M., E.J. Hansell, O. Behrendtsen, M.L. Flannery, N.S. Kishnani, S.P. Hawkes, and Z. Werb. 1996. Expression and function of matrix metalloproteinases and their inhibitors at the maternal-embryonic boundary during mouse embryo implantation. Development 122: 1723-1736.

Behrendtsen, O. and Z. Werb. 1997. Metal oproteinases regulate differentiation and migration of parietal endoderm in mouse embryos. Dev. Dyn. 208: 255-265.

Behrendtsen, O., C.M. Alexander, and Z. Werb. 1992. M etalloproteinases mediate extracellular matrix degradation by cells from mouse blastocyst outgrowths. Development 114: 447-456.

Beitel, G.J., S. Tuck, I. Greenwald, and H.R. Horvitz. 1995. The Caenorhabditis el egans gene lin-1 enclodes an ETS-domain protein and defines a branch of the vulval induction pathway. Genes \& Dev. 9: 3149-3162.

Berkowitz, E.A., K.B. Seroogy, J.A. Schroder, W.E. Russell, E.P. Evans, R.F. Riedel, H.K. Phillips, C.A. Harrison, D.C. Lee, and N.C. Luetteke. 1996. Characterization of the mouse tranforming growth factor $\alpha$ gene: Its expression during eyelid devel opment and in Waved 1 tissues. Cell Growth Differ. 7: $1271-1282$.

Bortner, D.M., S.J. Langer, and M.C. Ostrowski. 1993. N onnuclear oncogenes and the regulation of gene expression in transformed cells. Crit. Rev. Oncol. 4: 137-160.

Boulukos, K.E., P. Pognonec, B. Rabault, A. Begue, and J. Ghysdael. 1989. Definition of an Ets1 protein domain required for nuclear localization in cells and DNA-binding activity in vitro. Mol. Cell. Biol. 9: 5718-5721.

Boulukos, K.E., P. Pognonec, E. Sariban, M. Bailly, C. Lagrou, and J. Ghysdael. 1990. Rapid and transient expression of Ets2 in mature macrophages following stimulation with CMGF, LPS, and PKC activators. Genes \& Dev. 4: 401-409.

Brunner, D., K. Dücker, N. Oellers, E. Hafen, H. Scholz, and C. Klämbt. 1994. The ETS domain protein Pointed-P2 is a target of MAP kinase in the Sevenless signal transduction pathway. Nature 370: 386-389.

Chen, W.S., K. Manova, D.C. Weinstein, S.A. Duncan, A.S. Plump, V.R. Prezioso, R.F. Bachvarova, and J.E. Darnell Jr. 1994. Disruption of the HNF-4 gene, expressed in visceral endoderm, leads to cell death in embryonic ectoderm and imparied gastrulation of mouse embryos. Genes \& Dev. 8: 2466-2477.

Chomcznski, P. and N. Sacchi. 1987. Single-step method of RNA isolation by acid guanidinium thiocyanate-phenolchloroform extraction. Anal. Biochem. 162: 156-159.

Copp, A.J. 1995. Death before birth: Clues from gene knockouts and mutations. Trends Genet. 11: 87-93.

Donal dson, L.W., J.M. Petersen, B.J. Graves, and L.P. M clntosh. 1994. Secondary structure of the ETS domain places murine Ets-1 in the superfamily of winged helix-turn-helix DNAbinding proteins. Biochemistry 33: 13,509-13,516.

Duncan, S.A., A. N agy, and W. Chan. 1997. Murine gastrulation requires $\mathrm{HNF}$-4 regulated gene expression in the visceral endoderm: tetraploid rescue of $\mathrm{Hnf}-4-/-$ embryos. Development 124: 279-287.

Fujiwara, S., R.J. Fisher, N.K. Bhat, S. Espina, M. Diazdela, and T.S. Papas. 1988. A short-lived nuclear phosphoprotein encoded by the human ets- 2 proto-oncogene is stabilized by activation of protein kinase C. Mol. Cell. Biol. 8: 4700-4706.

Gack, S., R. Vallon, J. Schaper, U. Ruther, and P. Angel. 1994. Phenotypic al terations in Fos-transgenic mice correl ate with changes in Fos/Jun-dependent collagenase type I expression. J. Biol. Chem. 269: 10363-10369.
Galang, C.K., C.J. Der, and C.A. Hauser. 1994. Oncogenic Ras can induce transcriptional activation through a variety of promoter elements, including tandem c-Ets-2 binding sites. Oncogene 9: 2913-2921.

Galang, C.K., J.J. Garcia-Ramirez, P.A. Solski, C.J. Der, N.N. Neznanov, R.G. Oshima, and C.A. Hauser. 1996. Oncogenic neu/ErbB-2 increases Ets, AP-1, and N F-kB-dependent gene expression, and inhibiting Ets activation blocks $\mathrm{N}$ eu-mediated cellular transformation. J. Biol. Chem. 271: 7992-7998.

Ghysdael, J. and A. Boureux. 1997. The ETS family of transcriptional regulators. In Oncogenes as Transcriptional Regulators (ed. B. Yaniv and J. Ghysdael), pp. 29-89. Birkhauser Verlag, Basel, Switzerland.

Guillemot, F., A. Nagy, A. Auerbach, J. Rossant, and A.L. Joyner. 1994. Essential role of mash-2 in extraembryonic development. Nature 371: 333-336.

Gum, R., E. Lengyel, J. Juarez, J.H. Chen, H. Sato, M. Seiki, and D. Boyd. 1996. Stimulation of 92-kDa gel atinase B promoter activity by ras is mitogen-activated protein kinase kinase 1-independent and requires multiple transcription factor binding sites including closely spaced PEA3/ets and AP-1 sequences. J. Biol. Chem. 271: 10672-10680.

Gutman, A. and B. Wasylyk. 1990. The collagenase gene promoter contains a TPA and oncogene-responsive unit encompassing the PEA 3 and AP-1 binding sites. EMBO J. 9: 22412246.

Hardy, M.H. 1992. The secret life of the hair follicle. Trends Genet. 8: 55-61.

Hebert, J.M., T. Rosenquist, J. Gotz, and G.R. Martin. 1994. FGF5 as a regulator of the hair growth cycle: Evidence from targeted and spontaneous mutations. Cell 78: 1017-1025.

Henkel, G.W., S.R. McKercher, H. Yamamoto, K.L. Anderson, R.G. Oshima, and R.A. Maki. 1996. PU.1 but not Ets-2 is essential for macrophage development from ES cells. Blood 88: 2917-2926.

Henrique, D., J. Adam, A. Myat, A. Chitnis, J. Lewis, and D. Ish-H orowicz. 1995. Expression of a Delta homologue in prospective neurons in the chick. Nature 375: 787-790.

Hermann, B.G. 1991. Expression pattern of the Brachyury gene in whole-mount $T^{\text {Wis }} / T^{\text {Wis }}$ mutant embryos. Development 113: 913-917.

Hogan, B., F. Costantini, and E. Lacy. 1986. Manipulating the mouse embryo: A laboratory manual. Cold Spring Harbor Laboratory Press, Cold Spring Harbor, NY.

Karim, F.D., L.D. Urness, C.S. Thummel, M.J. Klemsz, S.R. M cKercher, A. Celada, C. VanBeveren, and R.A. Maki. 1990. The ETS domain: A new DNA binding motif that recognizes a purine-rich core DNA sequence. Genes \& Dev. 4: 14511453.

Kodandapani, R., F. Pio, C.-Z. Ni, G. Piccialli, M. Klemsz, S. McKercher, R.A. Maki, and K.R. Ely. 1996. A new pattern for helix-turn-helix recognition revealed by the PU.1 ETS-domain-DNA complex. Nature 380: 456-460.

Liang, H., E.T. Olejniczak, X. Mao, D.G. Nettesheim, L. Yu, C.B. Thompson, and S.W. Fesik. 1994. The secondary structure of the ets domain of human Fli-1 resembles that of the helix-turn-helix DNA-binding motif of the Escherichia coli catabolite gene activator protein. Proc. Natl. Acad. Sci. 91: 11655-11659.

Logan, S.K., M.J. Garabedian, C.E. Campbell, and Z. Werb. 1996. Synergistic transcriptional activation of the tissue inhibitor of metalloproteinases-1 promoter via functional interaction of AP-1 and Ets-1 transcription factors. J. Biol. Chem. 271: 774-782.

Luetteke, N.C., T.H. Qiu, R.L. Peiffer, P. Oliver, O. Smithies, and D.C. Lee. 1993. TGF $\alpha$ deficiency results in hair follicle 
and eye abnormalities in targeted and waved-1 mice. Cell 73: 263-278.

Luetteke, N.C., H.K. Phillips, T.H. Qiu, N.G. Copeland, H.S. Earp, N.A. Jenkins, and D.C. Lee. 1994. The mouse waved-2 phenotype results from a point mutation in the EGF receptor tyrosine kinase. Genes \& Dev. 8: 399-413.

Luo, J., R. Sladek, J.-A. Bader, A. M atthyssen, J. Rossant, and V. Giguere. 1997. Placental abnormalities in mouse embryos lacking the orphan nuclear receptor ERR- $\beta$. Nature 388: 778-782.

Mann, G.B., K.J. Fowler, A. Gabriel, E.C. Nice, R.L. Williams, and A.R. Dunn. 1993. Mice with a null mutation of the TGF $\alpha$ gene have abnormal skin architecture, wavy hair, and curly whiskers and often devel op corneal inflammation. Cell 73: 249-261.

Maroulakou, I.G., T.S. Papas, and J.E. Green. 1994. Differential expression of ets- 1 and ets-2 proto-oncogenes during murine embryogenesis. Oncogene 9: 1551-1565.

McCarthy, S.A., D. Chen, B.-S. Yang, J.J. Garcia Ramirez, H. Cherwinski, X.-R. Chen, M. Klagsbrun, C.A. Hauser, M.C. Ostrowski, and M. M CM achon. 1997. Rapid phosphorylation of Ets-2 accompanies mitogen-activated protein kinase activation and the induction of heparin-binding epidermal growth factor gene expression by oncogenic Raf-1. Mol. Cell. Biol. 17: 2401-2412.

McDonnell, S. and L.M. Matrisian. 1990. Stromelysin in tumor progression and metastasis. Cancer Metastasis Rev. 9: 305319.

M cKercher, S.R., B.E. Torbett, K.L. Anderson, G.W. Henkel, D.J. Vestal, H. Baribault, M. Klemsz, A.J. Feeney, G.E. Wu, C.J. Paige, and R.A. Maki. 1996. Targeted disruption of the PU.1 gene results in multiple hematopoietic abnormalities. EMBO J. 15: 5647-5658.

Miettinen, P.J., J.E. Berger, J. M eneses, Y. Phung, R.A. Pedersen, Z. Werb, and R. Derynck. 1995. Epithelial immaturity and multiorgan failure in mice lacking epidermal growth factor receptor. Nature 376: 337-341.

Mohammad, M., I. Dikic, A. Sorokin, W.H. Burgess, M. Jaye, and J. Schlessinger. 1996. Identification of six novel autophosphorylation sites on fibroblast growth factor receptor 1 and elucidation of their importance in receptor activation and signal transduction. Mol. Cell. Biol. 16:977-989.

Muthusamy, N., K. Barton, and J.M. Leiden. 1995. Defective activation and survival of $\mathrm{T}$ cells lacking the Ets-1 transcription factor. Nature 377: 639-642.

Nagy, A., E. Gocza, E. Merentes-Diaz, V.R. Prideaux, E. Ivanyi, M. Markkula, and J. Rossant. 1990. Embryonic stem cells alone are able to support fetal development in the mouse. Development 110: 815-821.

Neznanov, N.S. and R.G. Oshima. 1993. Cis regulation of the keratin 18 gene in transgenic mice. Mol. Cell. Biol. 13: 18151823.

O'N eill, E.M., I. Rebay, R. Tijan, and G.M. Rubin. 1994. The activities of two Ets-rel ated transcription factors required for Drosophila eye development are modulated by the Ras/ MAPK pathway. Cell 78: 137-147.

Oshima, R.G. 1981. Identification and immunoprecipitation of cytoskel etal proteins from murine extra-embryonic endodermal cells. J. Biol. Chem. 256: 8124-8133.

Oshima, R.G., J. M cKerrow, and D. Cox. 1981. Murine embryonal carcinoma hybrids: Decreased abiltiy to spontaneoulsy differentiate as a dominat trait. J. Cell. Physiol. 109: 195204.

Rabault, B., M.F. Roussel, C.T. Quang, and J. Ghysdael. 1996. Phosphorylation of Ets1 regulates the complementation of a CSF-1 receptor impaired in mitogenesis. Oncogene 13: 877-
881.

Rees, S., J. Coote, J. Stables, S. Goodson, S. Harris, and M .G. Lee. 1996. Bicistronic vector for the creation of stable mammalian cell lines that predisposes all antibiotic-resistant cells to express recombinant protein. BioTechniques 20: 102-110.

Reponen, P., C. Sahl berg, C. M unaut, I. Thesl eff, and K. Tryggvason. 1994. High expression of 92-kD type IV collagenase (gelatinase B) in the osteoclast lineage during mouse development. J. Cell Biol. 124: 1091-1102.

Rippe, R.A., S. Lorenzen, D.A. Brenner, and M. Breindl. 1989. Regulatory elements in the 5 '-flanking region and the first intron contribute to the transcriptional control of the mouse al pha 1 type I collagen gene. Mol. Cell. Biol. 9: 2224-2227.

Scott, E.W., M.C. Simon, J. Anastasi, and H. Singh. 1994. Requirement of transcription factor PU.1 in the development of multiple hematopoietic lineages. Science 265: 1573-1577.

Sibilia, M. and E.F. Wagner. 1995. Strain-dependent epithelial defects in mice lacking the EGF receptor. Science 269: 234238.

Stewart, T.A. and B. Mintz. 1981. Successive generations of mice produced from an established culture line of euploid teratocarcinoma cells. Proc. Natl. Acad. Sci. 78: 6314-6318.

Sympson, C.J., R.S. Talhouk, C.M. Alexander, J.R. Chin, S.M. Clift, M.J. Bissell, and Z. Werb. 1994. Targeted expression of stromelysin-1 in mammary gland provides evidence for a role of proteinases in branching morphogenesis and the requirement for an intact basement membrane for tissue-specific gene expression. J. Cell Biol. 125: 681-693.

Sympson, C.J., R.S. Talhouk, M.J. Bissell, and Z. Werb. 1995. The role of metalloproteinases and their inhibitors in regulating mammary epithelial morphology and function in vivo. Perspectives Drug Discovery Design 2: 401-411.

Threadgill, D.W., A.A. Dlugosz, L.A. Hansen, T. Tennenbaum, U. Lichti, D. Yee, C. LaM antia, T. Mourton, K. Herrup, R.C. Harris, J.A. Barnard, S.H. Yuspa, R.J. Coffey, and T. Magnuson. 1995. Targeted disruption of mouse EGF receptor: effect of genetic background on mutant phenotype. Science 269: 230-234.

Vecchi, A., C. Garlanda, M.G. Lampugnani, M. Resnati, C. Matteucci, A. Stopparcciaro, H. Schnurch, W. Risau, L. Ruco, A. Mantovani, and E. Dejana. 1994. M onoclonal antibodies specific for endothelial cells of mouse blood vessels. Their application to the identification of adult and embryonic endothelium. Eur. J. Cell Biol. 63: 247-254.

Wasylyk, C., A. Gutman, R. Nicholson, and B. Wasylyk. 1991. The c-Ets oncoprotein activates the stromelysin promoter through the same elements as several non-nuclear oncoproteins. EMBO J. 10: 1127-1134.

Wasylyk, B., S.L. Hahn, and A. Giovane. 1993. The Ets family of transcription factors. Eur. J. Biochem. 211: 7-18.

Watson, D.K., G.J. Mavrothalassitis, C.L. Jorcyk, F.E. Smyth, and T.S. Papas. 1990. M olecular organization and differential polyadenylation sites of the human ETS2 gene. Oncogene 5: 1521-1527.

Yamaguchi, T.P. and J. Rossant. 1995. Fibroblast growth factors in mammalian development. Curr. Opin. Genet. Dev. 5: 485-491.

Yang, B.-S., C.A. Hauser, G. Henkel, M.S. Colman, C. Van Beveren, K.J. Stacey, D.A. Hume, R.A. Maki, and M.C. Ostrowski. 1996. Ras-mediated phosphorylation of a conserved threonine residue enhances the transactivation activity of c-Ets1 and c-Ets2. Mol. Cell. Biol. 16: 538-547.

Zeitlin, S., J.-P. Liu, D.L. Chapman, V.E. Papaioannou, and A. Efstratiadis. 1995. Increased apoptosis and early embryonic lethality in mice nullizygous for the Huntington's disease gene homologue. Nature Genet. 11: 155-163. 


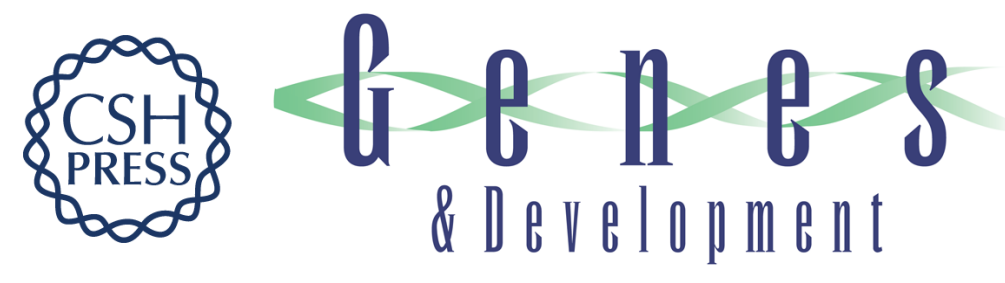

\section{Defective trophoblast function in mice with a targeted mutation of Ets2}

Hideyuki Yamamoto, Margaret L. Flannery, Sergey Kupriyanov, et al.

Genes Dev. 1998, 12:

References This article cites 61 articles, 31 of which can be accessed free at: http://genesdev.cshlp.org/content/12/9/1315.full.html\#ref-list-1

License

Email Alerting

Receive free email alerts when new articles cite this article - sign up in the box at the top Service right corner of the article or click here.

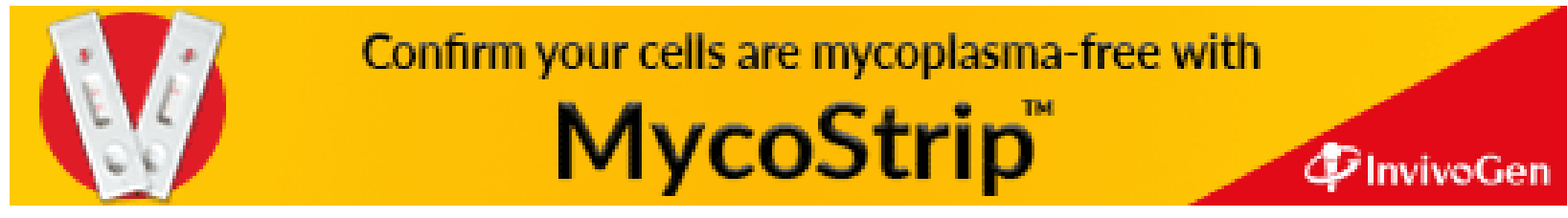

